\title{
Regional aspect in foreign language education (sociocultural competence)
}

\author{
Anastasia Yakovleva, Irina Savvina* \\ ${ }^{1}$ Institute of Foreign Philology and Regional Studies of M.K. Ammosov, North-Eastern Federal University, 58, Belinskogo St., \\ Yakutsk, 677000, Russia
}

\begin{abstract}
The regional aspect of language education plays a significant role in the development of sociocultural students' competence. The implementation of the regional component in university education is rarely considered, the issues of determining its content and role in the development of student competencies are not sufficiently developed. The way linguistic disciplines are currently taught in universities is undergoing a qualitative change, helping it meet the requirements of educational modernization, while the content and teaching methods are updated, and a competency-based approach to professional training is developed. The sociocultural competence occupies an important position together with the development of linguistic competence of students. The article presents the project results "Teaching the German language with the regional material" for the students of "45.03.01 Philology: Foreign philology (German language and literature)". A preliminary survey showed that $76 \%$ of students from 52 respondents were interested in studying regional material in the foreign language. The results discovered that our pedagogical approach increased the level of regional sociocultural competence of students, which contributed to the development of students' competency in the dialogue of cultures.
\end{abstract}

\section{Introduction}

University education realizes the approach that involves the use of regional material as a means of teaching a foreign language, as a source of knowledge. However, the issues of determining the content of the regional aspect and its role in the education of a student capable to conducting a dialogue with representatives of the world are not sufficiently developed. Textbooks usually include a lot of materials about the country of the language we study and only few texts about the native country. Thus, we can obviously say that we need to introduce cultural and regional materials in the teaching of foreign languages. As you know, sociocultural competence is both the knowledge about the culture of the country of the foreign language, and also the ability to talk about homeland, to represent region in intercultural dialogue. In order to be able to use different strategies of interaction with representatives of other cultures, students need to have a good knowledge of their own culture and native language, and the peculiarities of communication in their own community.

The subjectivity development among students in the dialogue of cultures requires the development of sociocultural competence. Foreign language knowledge does not always mean that a student is ready for successful intercultural communication. Insufficient development of the components of sociocultural competence, in particular, the regional component, may be one of the reasons of the ineffective intercultural interaction. Only a person who has understood foreignlanguage culture and who is well proficient in his/her native culture can solve rather difficult tasks of such interaction.

Some researchers distinguish structural elements of sociocultural competence and determine its content. V.V. Safonova believes that there are linguistic, cultural and sociolinguistic sub-competencies in the sociocultural competence structure [1]. Unlike this opinion, I.L. Bim determines four components in the sociocultural competence structure: presentive, sociolinguistic, universal cultural and cross-cultural competences. According to this author, the entire educational process should have a sociocultural orientation [2].

Sociocultural competence is closely related to intercultural competence. The authors, considering different components of the structure and content of sociocultural competence, agree that sociocultural competence is inseverable element of foreign-language communicative and intercultural competences.

G.V. Elizarova describes the theoretical foundations of intercultural competence in her works. The author considers the principle of culturally related co-study of native and foreign languages, the principle of ethnography, etc. among the main principles of intercultural competence [3].

The language education marks the regional aspect as its important component. A.A. Nasyrova considers the regional focused communicative competence as a part of regional and sociocultural competence in the concept. The author defines regional and sociocultural 
competence as "a set of the cross-curriculum knowledge reflecting specifics of the region and its professional environment and also skills and abilities to interpret and adequately to use this knowledge in a foreign language communication" [4, 73]. However V.P. Sysoyev divided competence into two elements: knowledge and activity, considers knowledge and experience in sociocultural competence [5].

Thus, the regional and sociocultural competence can be considered as a unity of knowledge about the region and sociocultural experience. Abilities to apply this knowledge and experience in cross-cultural interaction in a foreign language are a part of regional and sociocultural competence.

\section{Materials and Methods}

The language university introduces foreign-language culture to the individual, the subjectivity development in the dialogue of cultures, in the process of which the regional aspect plays a huge role. The process of socialization in foreign-language education is the development of a student's personality in introducing her/him into foreign-language culture on the basis of native culture. Socialization and education in the language university are aimed at the development of the student to interact in a foreign linguistic and cultural environment, to self-realization in a system of relations new to him. Micromodels of life situations - situations of intercultural experience, which are used in the practice of linguistic and pedagogical systems, play a big role in preparing students to get new experience.

As you know, one of the main tasks of socialization and education of students in the language universities is to teach them intercultural communication at various levels: global, interpersonal, preserving and developing the best features of a national character. We should take into account the ethnocultural factor that provides support for the human nature in the subjectivity development in the cultures dialogue. One of the main pecularities of the subject of cultures dialogue is the carrier of a certain culture.

So, socialization in the conditions of foreignlanguage education is also the development of sociocultural competence and intercultural experience. Intercultural experience is the result of interaction with the world of the studied language. To gain intercultural experience is not just to learn certain knowledge, but to develop ways of communication and activity.

Let's consider some of its components without claiming the exhaustive nature of the analysis of the components of intercultural experience: analytical, axiological, effective. Analytical component includes analysis of sociocultural situation in educational conditions or in real communication, analysis of communication process, analysis of own behavior in a situation, obtaining new knowledge, development of skills for successful intercultural communication. The analytical component is closely related to the axiological component, since cultural knowledge carries a value component, experiences and emotions are also involved here. A survey of students who participated in the academic exchange for a semester at foreign universities revealed new behavioral ideas in these students. Students analyzed the social situations they experienced, which indicated that students were directed to intercultural experience at the reflexive level. Indeed, the actualization of intercultural experience touches emotions, which in general is a complex psychological mechanism. After all, intercultural experience is the result of the interaction of a person - the carrier of culture with another linguistic and cultural environment. Here it is important how a person relates himself to another linguistic and cultural reality, enters certain social relations. The development of the linguistic university students' intercultural experience takes place in a specially organized linguistic pedagogical system, as well as in a foreign-language environment. The language university is considered as a linguistic and pedagogical system based on the concepts of N.V. Kuzmina, V.A. Yakunina's systematic approach to the phenomena of learning and education $[6,7]$.

Absence of knowledge of the characteristics of the region and its culture, lack of ability to represent it in a foreign language can hinder the full development of intercultural experience. The studied language is the main channel through which the student becomes involved in another culture, acquires intercultural experience, without losing his/her cultural identity, but also becoming a subject of intercultural dialogue.

An effective component of intercultural experience is that a student is ready for certain behavior in a sociocultural situation; the student focuses on the realization of ideas and values of both foreign language and native culture.

Students gain sociocultural competence during the educational process in foreign-language education: actions in sociocultural situations, development of communication ability in a foreign language, the analysis of the actions and behavior. Students' rules and norms, values of foreign-language linguocultural community; assessment of the phenomena and facts of the world of the learned language, comparison with realities of another country; transformation ideas of the world of the studied language to activity and behavior will develop the cross-cultural experience as a result of socialization in foreign-language education.

\section{Results and Discussion}

We paid special attention to the regional and sociocultural competence developing our own vision of content, methods of teaching the disciplines 45.03.01. Philology: Foreign philology (German and literature), in particular its variable part which allowed one to include disciplines with the regional aspect.

Thus, we need to determine the actual level of the regional focused knowledge as a part of sociocultural competence of students for understanding pedagogical conditions of development of regional and sociocultural competence of the personality, and subjectivity of students in cross-cultural dialogue. Then on the basis of 
studying initial level of the regional focused knowledge in German we could make the decision on inclusion of a regional component in the content of education, thereby to optimize the development of regional and sociocultural competence of students.

The trial groups were students of the German department of the Institute of Foreign Philology and Regional Studies in 2015-2016 and 2016-2017 academic years. The survey of students revealed a different level of proficiency in language and regional knowledge, containing national values and the realities of the region, background knowledge. We also used methods based on observations of personality activities and behaviour. A level analysis was used to confirm the conclusions drawn from the analysis of the research results. The questionnaire that we created reflected the generalized characteristics of the regional sociocultural competence of students, which were found in the knowledge, skills and behavior of students. The results made it possible to rank students by the activity of displaying the desired qualities. The data showed that differences in the levels of regional-sociocultural competence of students are manifested in the difference in the knowledge of vocabulary describing the realities of culture, the ways of transmitting the realities of the native language, the willingness to interact with nationalities of another linguistic cultural community, in particular, even the choice of vocabulary depends on the sociocultural situation, in the ability to apply sociolinguistic knowledge. Since a significant number of students turned out to be with a low level of regional sociocultural competence - $52 \%$ of the total number of students surveyed, it was necessary to determine ways to optimize the development of this knowledge.

For these purposes, we have created the project "Teaching the German language to bachelor-philologists with the use of regional material" within the disciplines of the variable part of the curriculum. 45.03.01 Philology: Foreign philology (German language and literature). This project was due to the need to fill the educational program with additional material related to the inclusion of the regional component in the content of educational process.

The project "Teaching the German language to bachelor-philologists with the use of regional material" should have improved regional knowledge in a foreign language. A preliminary survey showed that $76 \%$ of all surveyed students were interested in studying regional material in a foreign language to further selfdevelopment.

As part of the project, the discipline "Ethnic Socialization of the Yakuts" (in German) was included in the additional part of the curriculum (variable discipline). Prior to the inclusion of our discipline in the faculty curriculum, the content of the project work was determined, which was long in time and informative, a teaching manual "Deutschunterricht durch regionales material" was created. Thus, the project was organized within the framework of the discipline "Ethnic socialization of the Yakuts" (in German) and used the educational and methodological manual "Deutschunterricht durch regionales material". The first part of the manual compared the Yakut language "Jakutisch" with the German one. For example, the topic "Laute und Buchstaben im Jakutischen. Das jakutische Alphabet" compared Yakut and German letters.

The first part also includes material for discussing cases of influence of the native language of students: "Die Hör-Sprech-Fertigkeiten werden auf das Deutsche übertragen, und es entstehen Probleme der Interferenz der negativen Einwirkung der Muttersprache. Einige Hör-Sprechfehler trifft man nicht selten. Es ist schwer für sie den reduzierten, unbetonten Vokal [ə] am Ende des Wortes auszusprechen wie zum Beispiel in den Wörtern: haben, heben, essen.

Der Vokal [ə] wird ziemlich klar ausgesprochen, obwohl dieser Vokal im Deutschen sehr unklar ist. Hier kann jakutischer kurzer [e] wirken (wie im jakutischen Wort kürülgen-Wasserfall). Ein langes, gespanntes [e:] kann durch ein langes, ungespanntes [ $\varepsilon$ :] ersetzt werden (wie zum Beispiel in den Wörtern lesen, Ehre, geben, Leder. Hier beobachten wir die Einwirkung der Muttersprache - der jakutischen Sprache» (Listening skills were transmitted into German, and interference problems arise - the negative impact of the mother language. Some auditory mistakes were common. It is difficult for them to pronounce a reduced, unstressed vowel [ə] at the end of a word, for example, in words: to have, to raise, to eat.

The vowel [ə] is pronounced quite clearly, although this vowel is very unclear in German. Here a short Yakut [e] can influence (as in the Yakut word kürülgen - waterfall). A long, tense [e:] can be replaced by a long, not tense [ $\varepsilon$ :] (for example, in the words "read, honor, give, skin"). Here we observe the influence of the native language - the Yakut language).

The positive influence of the Yakut language on the pronunciation of German sounds is also discussed: "Es gibt auch positive Übertragungen vom Jakutischen ins Deutsche. Aussprache solcher Laute wie: [n], [ø:], [œ], [Y:], [Y], [h] ist leicht für Studenten. Jakutische Vokale [y],[y:];[œ],[ø:] beim Hören sind ähnlich den deutschen Vokalen [y], [y:], [œ],[ø:], aber bei Aussprache gibt es Unterschiede, z.b., der deutsche Vokal [ $\varnothing$ :] im Vergleich mit dem jakutischen [ $\varnothing:]$ ist geschlossener. Darüber schrieb deutschstämmiger russischer Forscher, Sprachwissenschaftler Otto von Böhtlingk (1815-1904) in seinem Werk "Über die Sprache der Jakuten" (1851)" [8].

\begin{tabular}{|c|c|}
\hline Deutscher [ø:] & Jakutischer [ø:] \\
\hline böse [bø:zə] & бөөлуун [bø:ly:n] \\
\hline löten [lø:tən] & төлөө [tœlø:] \\
\hline
\end{tabular}

There are also positive transfers from Yakut to German. Pronunciation of such sounds as: [y], [ø:], [œ], [Y:], [Y], [h] is easy for students. Yakut vowels [y], [y:], [œ], [ø:] are aurally similar to German vowels [y], [y:], [œ], [ø:], but when pronouncing there are distinctions. 
For example, the German vowel [ $\varnothing$ :] is more closed than the Yakut one [ø:]. This was written by a Russian researcher of German origin, linguist Otto von Bötlingk (1815-1904) in his work "About the Language of the Yakuts" [8].

The second part of the teaching manual presents material on socialization and education in ethnoculture to update the system of values of native culture and existing cultural and regional knowledge on the topic among students, as well as to study the meaningful parameter of experience as part of the regional sociocultural competence of students. Students should fill out the diagram after reading the text. For example, on the topic «Die Sozialisation in der jakutischen Familie: Traditionen und gegenwärtige Tendenzen» (Socialization in the Yakut family: traditions and modern trends):

1. Lesen Sie den Text 1. Ordnen Sie Merkmale der Erziehungspraxis von Jakuten in das Analyseraster ein.

2. Analysieren Sie Erziehungspraxis in einem von Ihnen selbst gewählten deutschsprachigen Land, z.B. in einem Land,

- in das Sie eine Fahrt unternommen haben oder unternehmen wollen,

- das Sie schon im Pädagogikunterricht oder in einem anderen Fach besprochen haben.

Sie haben Erziehungspraxis am eigenen Leibe erfahren haben. Sie konnten zudem in Ihrem eigenen Lebenskreis (Familie, Nachbarschaft, Schule, Jugendgruppe usw.) täglich Erfahrungen machen. Aufgrund eigener Beobachtungen haben Sie Schilderungen der Kindererziehung.

Tragen Sie auch von Ihnen gefundene Merkmale der Erziehungspraxis in das Analyseraster ein, so wie Sie es auch mit den Ergebnissen der Textanalyse gemacht haben.

Achten Sie dabei auf:

aktive und passive Erziehungsmaßnahmen in den ersten Lebensjahren,

$$
\text { mit welchen Mitteln erfolgen }
$$

Reinlichkeitserziehung, Laufen lernen und Erziehung zum Gehorsam?

- welche Erziehungsmittel werden im Alltagsleben angewandt?

1. Read the text 1. Add signs of educational practices of Yakuts to the analysis scheme.

2. Analyze the practice of education in your chosen German-speaking country, for example, in the country:

- which you have been in, or want to visit;

- or what you have already discussed in classes.

You have experienced the practice of educating yourself. In addition, you could get daily experience in your own areas of life (family, neighbors, school, youth group, etc.), describe raising children based on your own observations.

Also include the characteristics of education practices you have discovered in the analysis scheme in the same way as the results of text analysis.

Note the following:

- Active and passive methods of education in the early years of life.
- What methods of education teach children hygiene, walking and obedience?

- What methods of education are used in everyday life?

The project activities of the students were coordinated by the teacher of the discipline and sent in a sequence plan. Students were provided with pedagogical support in fulfilling tasks. The pedagogical interaction in the conditions of the project was aimed at the positive aspects of the student's activities; the teacher strengthened the student's faith in themselves and their opportunities.

\section{Conclusion}

The main project goal was the development of linguistic and regional studies and sociocultural competencies of students to solve the problems of interpersonal and intercultural interaction. It was necessary to help a graduate to participate actively in intercultural dialogue based on the regional science in a foreign language.

In the process of teaching the German language including regional material, students learned to make a project regarding the content of regional material: make questions, develop practical tasks, make presentations and others. The project was aimed at developing students' skills in description, presentation of their native language and ethnoculture in German. The implementation of the project included the following training activities: search, compilation and presentation of regional materials, a description of regional concepts in German, interpretation of cultural, regional material; updating of training materials in the process of creation of tasks, questions on topics; Introduction of a regional aspect in situational and communication activities; performing a complex of cognitive search, contrastcomparative, communication-cognitive, problem and speech tasks, etc.

These methods helped to develop the subjectivity of students in intercultural interaction, as well as learned students-future teachers to integrate the regional component into German language education, to compile programs using the regional component, to include regional material in the content of German language education. The fact that the number of students with a low level of regional studies and sociocultural competence became $22 \%$. Initially there were $52 \%$, which was a fairly significant indicator. The considerable number of students with the average level of regional-sociocultural competence was $45 \%$ (firstly there were $32 \%$ ) and high level of regional-sociocultural competence became 33\%. (initially there were $16 \%$ ). We can say that the project became that factor which contributed to the development of both linguistic and regional-sociocultural competence. It improves creativity, and possibilities to change the teaching forms.

The development and implementation of a regional component in the content of the training of bachelorphilologists, taught students how to present materials about the region in German. It developed intercultural 
interaction skills on linguistic and linguistic ethnopedagological material, contributed to the development of regional sociocultural competence among students. The inclusion of the regional aspect in the language training of students contributes to the development of the subjectivity of students in the dialogue of cultures.

Thus, we have implemented:

- the regional aspect into student's language education

- the project in the foreign language learning

- teaching a special regional aspect discipline within the variable part of the curriculum

- a teaching regional manual in a foreign language

- pedagogical support of students in performing creative tasks contributed to the development of students' regional sociocultural competence.

\section{References}

1. V.V. Safonova, The study of languages of international communication in the context of dialogue of cultures and civilizations (1996)

2. I.L. Bim, The concept of teaching a second foreign language (German based on English) (2001)

3. G.V. Elizarova, The development of intercultural competence of students in the process of teaching foreign communication (2001)

4. A.A. Nasyrova, The development of regionaloriented communicative competence of a bachelor of linguistics (2013)

5. V.P. Sysoev, Cultural self-determination of students in the conditions of linguistic multicultural education, Foreign languages in school, 4, 14 (2004)

6. N.V. Kuzmina, Methods of system of pedagogical research (1980)

7. V.A. Yakunin, Pedagogical psychology (1998)

8. O. Bötlingk, Über die Sprache der Jakuten (About the language of the Yakuts) (1851)

9. A.N. Yakovleva, Linguopedagogics as a problem of interdisciplinary research (Education and science, 7 (96), 125 (2012) 